УдК 338.43.01

DOI: 10.24144/2078-1431.2019.2(23).115-126

Леся Газуда,

доктор економічних наук, професор, професор кафедри економіки і підприємництва

Вікторія Герцег, аспірантка кафедри економіки і підприемництва ДВНЗ «Ужгородський національний університет»

\title{
НАУКОВО-МЕТОДИЧНІ ЗАСАДИ ОЦІНЮВАННЯ РОЗВИТКУ СІЛЬСЬКИХ ТЕРИТОРІЙ: УКРАЇНСЬКИЙ ТА МІЖНАРОДНИЙ ДОСВІД
}

Сучасний стан економіки України та прагнення інтеграціӥ до європейського співтовариства зумовлюють необхідність суттевих змін у сфері управління на всіх рівнях. Водночас виникае потреба у розробленні управлінських заходів $i$ окресленні механізмів забезпечення збалансованого розвитку сільських територій як у крайні в цзілому, так і на рівні окремо взятого регіону.

У статті розглянуто науково-методичні засади оцінювання сучасного стану розвитку сільських територій, наведено його структурну схему та ключові етапи, трактування поняття «оцінка», охарактеризовано складові елементи зазначеного оцінювання, зокрема показники, індикатори, коефіцієнти. Висвітлено міжнародний досвід забезпечення соціально-економічного розвитку сільсъких територій.

Ключові слова: сільські територї, збалансований розвиток, оцінювання, методи дослідження, показники.

The current state of the economy of Ukraine and the desire for integration into the European Community necessitates significant changes in governance processes at all levels, requires the development of measures and mechanisms for the sustainable development of the Ukrainian village and the earliest possible decision-making in this field. It is worth noting that rural areas are a very difficult object of research and management, so there is a need to determine methodological approaches to assess their status, strategic priorities for overcoming negative trends that hinder their development, finding ways to solve emerging problems and components to ensure the comprehensive development and development of the Ukrainian village.

The article deals with the scientific and methodological bases of assessment of the current state of rural development, the interpretation of the concept of "evaluation", the structural scheme and key stages of the assessment of rural development, the constituent elements of the assessment: indicators, indicators, coefficients, highlighted the international experience of ensuring the socio-economic development of rural areas. General scientific and special economic methods are applied in the article. In particular: analysis and synthesis, induction and deduction, abstract-logical, economic-mathematical modeling. 
The aforementioned studies provide a strong methodological and methodological basis for determining the status of rural areas, identifying external and internal threats of socio-economic nature. It is worth noting that there is no single commonly agreed set of partial indicators for assessing social infrastructure. The most commonly used indicators used to assess the development of rural territories are those provided by the State Statistics Office, whose analysis and comparison over the years makes it possible to assess the status and identify changes in the socio-economic phenomena of the studied territories.

Carrying out such an assessment makes it possible to identify external and internal threats of socio-economic and environmental character, facilitates the development of a set of effective measures for institutional regulation, identifying key areas for rural development.

Keywords: rural areas, sustainable development, evaluation, research methods, indicators.

Метою статmі є узагадьнення методичних підходів до оцінювання розвитку сільських територій, аналіз інституційних показників, які відображають їх соціально-економічний стан.

Постановка проблеми. Нині оцінювання сучасного стану соціальноекономічного розвитку сільських територій набуває актуальності, оскільки виникає необхідність моніторингу досліджуваних територій з метою виявлення проблемних питань їх розвитку, а в подальшому і вирішення. Зазначимо, що протягом останніх десятиліть в Україні відбулися значні трансформаційні перетворення в аграрному секторі економіки, але всупереч цьому спостерігається погіршення якості життя сільського населення (зниження доходів і рівня життя сільських мешканців), відпдив молоді та працездатного населення у міста чи за межі країни у пошуках кращого життя, що спричинюе демографічні, етнічно-культурні проблеми.

Ключовим аспектом процесу дослідження сільських територій є розроблення методичних підходів, виокремлення інструментів їх оцінювання, аналіз показників їх розвитку, які б максимально враховували територіальні, економічні, екологічні, інституційні складові досліджуваних територій. Актуалізації набуває моніторинг багатофункціональності сільських територій, ефективне задіяння яких сприятиме перспективному зростанню сільськогосподарського виробництва, підвищенню рівня добробуту та благополуччя сільських мешканців. Моніторинг зазначених проблем дасть можливість окреслення підходів та пошуку механізмів до їх вирішення.

Аналіз останніх досліджень. Виокремлення методичних засад оцінювання розвитку та відродження сільських територій залишається важливим завданням, яке варто дослідити як на регіональному, так і на державному рівні. Проблеми ефективного оцінювання та аналізу стану сільських територій відображено у наукових працях вчених-економістів: О. Бородіна, В. Борщевського, С. Мочерного, В. Андрійчука, А. Сидорової, Н. Вітренка, М. Миколайчука, А. Лісового та інших.

Виклад основного матеріалу. Функціонування українського села базується на поєднанні принципів адміністративно-територіальної, вироб- 
ничої, економічної, соціальної та екологічної складової на основі взаємоузгодження та взаємодоповненості. Взаємозумовленість зазначених принципів впливає на результативність та якість життя сільського населення, здатність задовольняти соціальні потреби та ефективність різних сфер виробництва на відповідних територіях. Вирішення подальших теоретичних і практичних завдань стосовно забезпечення сталого розвитку сільських територій потребує розроблення дієвого алгоритму, структурної схеми, систематизації методів та показників дослідження сучасного стану сільських територій. При цьому доцільним є застосування загальнонаукових та спеціальних економічних методів і прийомів, зокрема аналізу та синтезу, індукції та дедукції, абстрактно-догічного, економіко-математичного моделювання тощо.

У тлумачному словнику терміни «оцінка» та «оцінювання» визначаються як характеристика якості виконання дослідження (фактичного ефекту) стосовно попередньо закладених припущень (очікуваного ефекту) або як процедура оцінювання, що спирається на попередні результати та виконуеться з метою перевірки їх ефективності; оцінювання - сукупність різнобічних оцінок, що трактуються як такі, що характеризують стан досліджуваного явища та процесу з метою його якісної та кількісної характеристики [18].

Поняття «оцінка» часто ототожнюють із поняттям «моніторинг». Моніторинг більш загальне поняття, яке передбачає систематичне відстеження стану, процесів або тенденцій, постійне спостереження за об'єктом 3 метою виявлення виникаючих ситуацій та несприятливих факторів.

3 метою оцінювання кількісного та якісного стану сільських територій необхідно застосовувати систему показників та індикаторів, які дають розгорнуту характеристику соціально-економічних процесів та явищ, що відбуваються у межах сільських територій.

Оскільки, як ми вже відмічали, сільські території - це багатофункціональна система, то формування оцінки їх ефективності потребує комплексного підходу, який передбачає визначення алгоритму дій та поетапного окреслення окремих показників. Розглянемо ключові етапи оцінки розвитку сільських територій (рис. 1).

І етап - підготовчий. Передбачає визначення мети дослідження, об'єкта, предмета, а також аналіз зовнішнього та внутрішнього середовища. Зовнішне середовище сільських територій формується під впливом різних факторів: природних, екологічних, демографічних, соціально-культурних, географічного розташування та інших. До внутрішнього середовища сільських територій варто віднести: потенціал території, організацію управління, соціально-економічну сферу, стиль життя населення та інші.

Наступні етапи доцільно назвати розрахунково-аналітичними.

II етап - визначення системи показників для оцінки ефективності розвитку сільських територій, розподіл їх за категоріями (інституційна складова, економічна складова, соціальна складова, екологічна складова).

III етап - розрахунок групових та інтегральних показників, узагальнюючих коефіцієнтів, що відображають рівень сільського розвитку. 


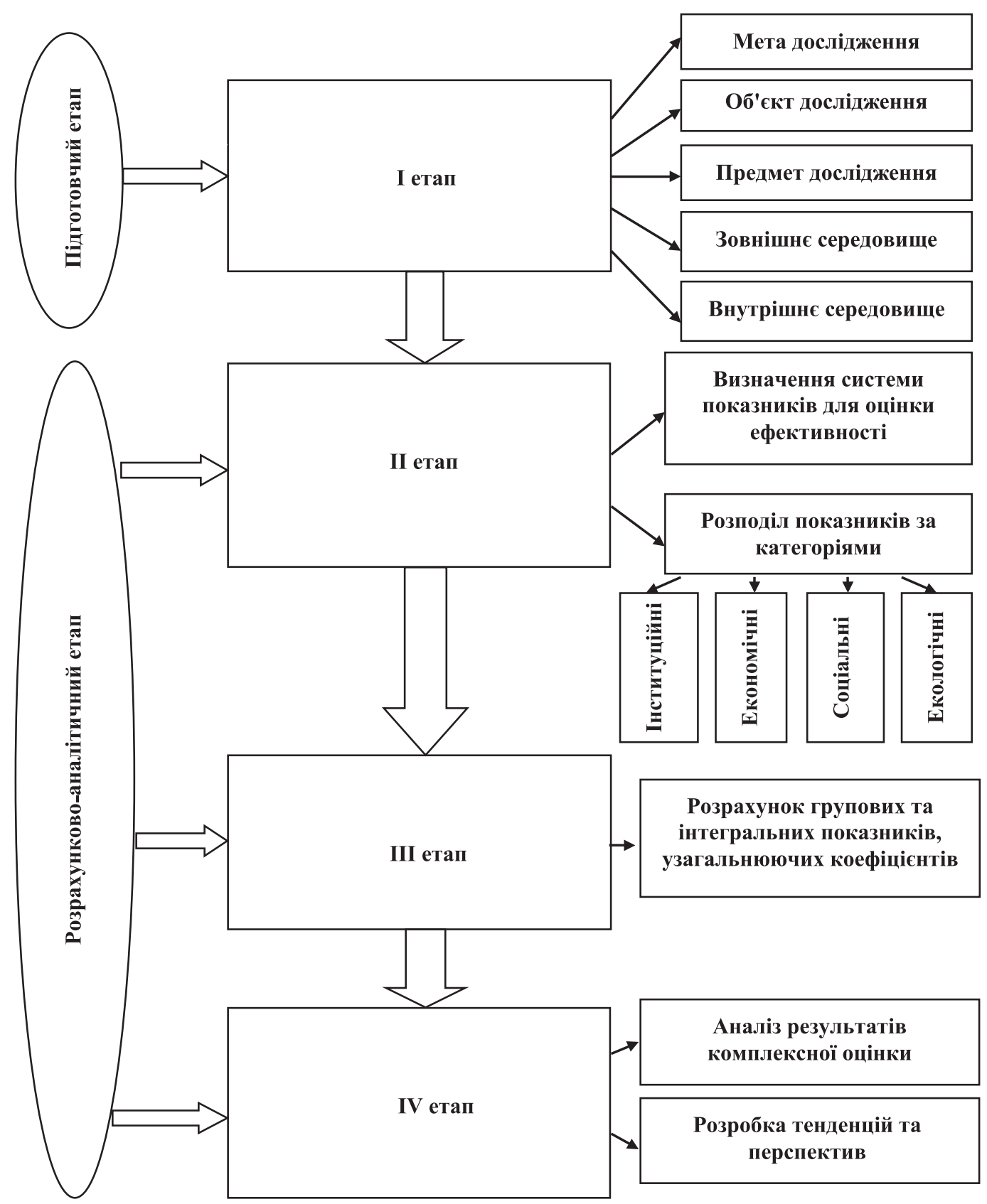

Рис. 1. Основні етапи оцінки розвитку сільських територій*

* Джерело: авторські дослідження

IV етап - аналіз результатів комплексної оцінки, тенденцій та перспектив сільського розвитку.

Важдивим для оцінювання розвитку сільських територій є визначення методичних підходів до процесу дослідження. Т. Зінчук та Н. Куцмус у своїх дослідженнях виділяють три групи індикаторів сільського розвитку: детерміновані, фіксовані та результативні [7, с. 8-10]. 
Детерміновані індикатори надають характеристику ресурсного забезпечення та соціального розвитку. До них відносять: валовий внутрішній продукт (ВВП), національний дохід (НД) на одну особу сільського населення, продуктивність сільськогосподарської праці, інвестиції на соціальні та природоохоронні заходи, видатки на утримання і розвиток соціальної та інженерної інфраструктури, обсяги державної допомоги (пільги, компенсації сільським жителям та суб'єктам господарювання).

Фіксовані індикатори характеризують стан соціальних процесів та явищ. До них належать:

1) показники стану населення: чисельність і густина населення, природний та механічний рух, статевовікова структура;

2) зайнятість: рівень та інтенсивність зайнятості сільського населення, галузева і демографічна структура зайнятості;

3) рівень життя: розмір доходів сільського населення, рівень споживання, стан та розвиток ринку товарів та послуг, рівень бідності сільського населення;

4) показники соціальної інфраструктури: забезпечення сільськогосподарського населення основними інфраструктурними об'єктами, рівень розвитку інформаційних систем та консультування населення.

Результативні індикатори - характеризують параметри соціального добробуту сільського населення. Зокрема, рівень мотивації праці, матеріальний стан сільського населення, стан здоров'я сільського населення, рівень освіти, соціальна безпека.

До прикладу, розглянемо методи розрахунку окремих вищезгаданих показників, які варто застосувати для певного чітко визначеного об'єкта (сільської території).

Валовий внутрішній продукт (ВВП) - сукупна вартість кінцевої продукції, виготовленої на території тієї чи іншої країни за певний проміжок часу (за рік), незалежно від того, знаходяться фактори виробництва у власності громадян країни чи належать іноземцям [5].

ВВП - сума валової доданої вартості (ВДВ) галузей плюс чисті податки на продукти (ПДВ) (ЧПІ) не зараховані до неї:

$$
\text { ВВП = } \Sigma \text { ВДВ }+ \text { ПДВ, ЧПІ. }
$$

ВНД відрізняється від валового внутрішнього продукту на сальдо (різницю між грошовими надходженнями і витратами) зовнішньоекономічних операцій, включаючи сальдо експорту та імпорту товарів і послуг, сальдо оплати праці чужоземних працівників і сальдо переведення прибутків від вивезеного за кордон капіталу.

Щоб отримати ВНП, потрібно до ВВП додати надходження за фактори виробництва від решти країн світу (прибутки, зарплата, зароблені резидентами за кордоном) і відняти платежі за фактори виробництва решті країн світу (прибутки, зарплата, зароблені іноземцями в країні).

На основі ВВП можна розрахувати й низку інших показників:

- чистий внутрішній продукт (ЧВП). Він визначається шляхом віднімання від ВВП відрахувань на споживання капіталу або амортизації. 


\section{ЧВП = ВВП $-\mathbf{A}$}

У системі національних рахунків особливу значущість має національний дохід (НД).

НД- це весь дохід, зароблений упродовж року власниками ресурсів, що є резидентами певної держави, незалежно від того, де ці ресурси використовуються - у власній країні чи за кордоном. Для визначення національного доходу з ВНП необхідно вирахувати амортизацію та непрямі податки на бізнес:

\section{НД = ВНП - Амортизація - Непрямі податки.}

Аналіз найбільш часто вживаних показників, що використовуються для оцінки соціально-економічного розвитку, довів, що частіш за все ці показники є показниками, які наводяться Державним управдінням статистики. Не існує єдиного визначеного набору часткових показників для комплексної оцінки стану сільських територій, що ускладнюе процес та спонукає до пошуку узагальнюючих індикаторів.

3 метою врахування основних тенденцій у розвитку економіки регіонів широкого застосування набув інтегрований показник, що відображає основні чинники формування ВВП:

$$
\mathrm{I}_{\mathrm{вп}}=0,3 \mathrm{I}_{\mathrm{пв}}+0,3 \mathrm{I}_{\mathrm{x \Pi}}+0,3 \mathrm{I}_{\mathrm{cп}}+0,1 \mathrm{I}_{\mathrm{cr}},
$$

де $\mathrm{I}_{\text {вп }}$ індикатор випуску продукції та наданих послуг;

$\mathrm{I}_{\text {пв }}$ - індикатор промислового виробництва;

$\mathrm{I}_{\text {хп }}$ - індикатор виробництва продукції харчової промисловості;

$I_{\text {сп }}$ - індикатор вартості наданих послуг;

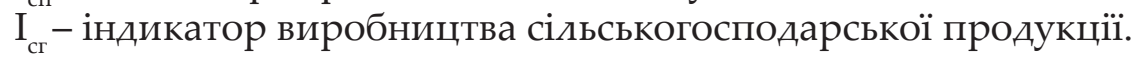

Коефіцієнти 0,3 та 0,1 враховують вагомість окремих показників у загальній оцінці. Їх значення отримані за допомогою методу факторних навантажень. Розрахунок кожної складової базується на інформації, що публікується у щорічних статистичних довідниках Державного комітету статистики України та його обласних управліннях [13, с. 7].

Рівень розвитку соціальної інфраструктури сільської територї обчислюеться за показниками:

- житлова площа на 1 особу, кв. м.;

- забезпеченість сільських будинків та квартир природним газом, \%;

- забезпеченість населених пунктів дитячими закладами дошкільної освіти, \% (визначається як відношення сільських поселень, що мають відповідні заклади до всіх сільських населених пунктів, в яких є діти до 5 років);

- забезпеченість закладами освіти (школами), \%;

- забезпеченість закладами охорони здоров'я (дікарнями), \%;

- забезпеченість спортивними спорудами, \%;

- забезпеченість сільських населених пунктів дорогами з твердим покриттям, \% [11, с. 9]. 
Існує низка підходів до інтеградьної оцінки економічного зростання території. Найбільш поширені з них - інтегральний темповий індекс економічного зростання території, індикатор стійкості економічного зростання, індекс економічного розвитку Тейла, який відображає економічне зростання за рахунок порівняння і логарифмування районного та регіонального показників обсягів виробництва та чисельності населення:

$$
\mathrm{IT}=\sum_{i-1}^{n} \frac{Y_{i}}{Y} \ln \frac{Y_{i} P_{j}}{Y_{/} P},
$$

де $Y_{i}$ - обсяг валового виробництва продукції у районі і $Y$ - валовий регіональний продукт у регіоні; $P_{j}, P$ - чисельність населення відповідно району і регіону.

У міжнародній практиці провідну роль для оцінювання стану сільських територій та забезпечення соціально-економічного розвитку відіграє такий показник, як індекс дюдського розвитку (ДР). ІИР - інтеградьний показник, синтезує варіанти вибору тривалого і здорового життя, набуття знань, доступ до ресурсів, необхідних для підтримання гідного рівня життя. Він вважається стандартним інструментом при загальному порівнянні рівня життя різних країн і регіонів. Індекс публікуеться в рамках програми розвитку ООН в звітах про розвиток людського потенціалу і був розроблений в 1990 р. групою економістів на чолі з пакистанцем Махбубом-уль-Хаком. Однак концептуальна структура індексу була створена завдяки роботі Амарт'я Сена. Індекс публікуеться $\mathrm{OOH}$ у щорічному звіті про розвиток людського потенціалу з 1990 р. [8].

ИР розраховується як середня арифметична зі стандартних показників, що входять до їі складу [1, с. 11-12]:

$$
\text { ІЛР }=\frac{\text { ІД }+ \text { ІОС }+ \text { ІРж}}{3},
$$

де $\mathrm{I}_{A}$ - індекс очікуваного довголіття;

$\mathrm{I}_{\mathrm{OC}}$ - індекс освітнього рівня;

$\mathrm{I}_{\text {Рж }}$ - індекс рівня життя.

При цьому стандартизовані показники, наведені в чисельнику, обчислюються за формулою:

$$
\mathrm{I}=\frac{\mathrm{X} \phi-\mathrm{Xmin}}{\mathrm{X} \max -\mathrm{X} \min }
$$

де $\mathrm{X}_{\phi}$ - фактичне значення показника;

$X_{\min }, X_{\max }-$ відповідно мінімальне та максимальне значення цього коефіцієнта, які прийнято за еталон у міжнародній практиці.

Зокрема, за еталон прийнято такі мінімальні та максимальні значення відповідних показників.

Очікуване довголіття, років:

$\mathrm{X}_{\min }$ У цілому для населення - 25; для чоловіків - 22,5; для жінок - 27,5;

$\mathrm{X}_{\max }-$ відповідно 85; 82,5; 87,5. 
Досягнутий рівень освіти:

$X_{\min }$ - грамотність дорослого населення та учнів становить 0\%;

$X_{\max }-100 \%$.

Рівень життя, дол. США ПКС:

$X_{\min }-100$

$X_{\max }-40000$.

Показники $\mathrm{I}_{\text {ос }}$ та $\mathrm{I}_{\text {рж }}$ мають деякі особливості розрахунку. Так, показник досягнутого рівня освіти обчислюється 3 використанням вагових коефіцієнтів: для дорослого населення $\left(\mathrm{I}_{\Gamma \mathrm{P}}\right)-2 / 3$; для сукупної частки учнів $\left(\mathrm{I}_{\mathrm{yч}}\right)-1 / 3$.

$$
\mathrm{I}_{\mathrm{OC}}=\frac{2}{3} \mathrm{I}_{\Gamma \mathrm{P}}+\frac{1}{3} \mathrm{I}_{\mathrm{yч}} \text {. }
$$

Міжнародна методика використовує тільки ту інформацію, яка збирається за всіма без винятку країнами. Статистична база України дає змогу врахувати значно більше коло факторів, що визначають дюдський розвиток. Визначення ІЛР має окремі недоліки: ураховуються винятково позитивні характеристики (стимулятори) людського розвитку (чим вище значення показника, тим вищий рівень гуманітарного розвитку досліджжуваного об'єкта), поза увагою залишаються негативні індикатори (дестимулятори) розвитку суспільства (наприклад, стан злочинності, рівень безробіття тощо). Тому, аби визначити причинно-наслідкові фактори та можливі політичні рішення, необхідним є більш виважений і реалістичний погляд на схожість та відмінності регіонів, що спонукало до розроблення методики побудови регіональних індексів людського розвитку, яка завдяки наявній інформаційній базі дала б змогу істотно розширити коло індикаторів та відмовитись від гіпотези рівнозначності окремих складових.

Одним 3 провідних методів стратегічного планування та управдінської практики є SWOT-аналіз. Результатом його застосування є матриця, яка відображає стратегічні напрями розвитку території, визначені з урахуванням їі слабких та сильних сторін. Цей метод можна конкретизувати, застосовуючи SWOT-аналіз, який здебільшого відображає характеристику зовнішніх чинників розвитку сільської території та її положення в системі координат стадій розвитку, за яких більш ефективними є стратегія успіху, стратегія збереження, стратегія конкуренції чи стратегія захисту[2].

Завершальним етапом оцінювання стану досліджуваних територій $є$ аналіз результатів комплексної оцінки, тенденцій і перспектив сільського розвитку та розробка відповідних програм стимулювання їх розвитку.

Світовий досвід розвитку сільських територій у контексті реалізації державної політики забезпечення економічної безпеки можна виокремити за трьома групами країн [4,с.76-79]:

І група - це країни, де сільське господарство перебуває у стані ведення натуральної форми виробництва, а сучасні ринкові механізми функціонування відносин у аграрній сфері потребують значного розвитку. Причинами цього є ресурсна обмеженість територій, неефективне використання наявного ресурсного потенціалу, низький рівень господарювання. Сільське господарство формує значну частину ВВП, але ці держави не спро- 
можні забезпечити себе сповна продовольчими товарами. Це переважно країни Латинської Америки (Колумбія, Перу, Чилі) та Північної Африки (Алжир, Судан, Туніс).

II група - держави, що пройшли період реалізації структурних перетворень, провели аграрну реформу, однак такі трансформаційні процеси не привели до потужного соціально-економічного розвитку сільських територій та не забезпечили суттєвого зростання рівня життя сільського населення. Для них характерним є розвинене сільське господарство, що дозволяе забезпечити себе продовольчими товарами на належному рівні, однак доходи від сільськогосподарської діяльності неефективно використовуються та не спрямовуються на забезпечення розвитку сільськогосподарських територій і підвищення рівня життя сільських жителів. До цієї групи держав належать: Білорусь, Болгарія, Казахстан, Молдова, Словаччина, Угорщина, Хорватія та інші.

III група - економічно розвинені держави, що перебувають у стані трансформаційних процесів сталого розвитку. У цих країнах проведено аграрну реформу, відбулися якісні структурні зміни в сільському господарстві, позитивні зрушення у вирівнюванні диспропорцій між розвитком сільських та урбанізованих територій, що призвело до підвищення рівня життя сільських жителів. До цієї групи держав належать: Канада, Німеччина, Іспанія, Португалія,Польща, США, Франція, Чехія та інші.

Стосовно України, то ії можна віднести до другої групи країн у контексті реалізації державної політики забезпечення економічного розвитку сільських територій. Перспективні напрями формування зазначеної політики повинні враховувати науково-технічну, інформаційну та інноваційну основу, а також досвід розвинутих країн. Запозичення і впровадження досвіду країн, що належать до третьої групи, в Україні сприятиме формуванню результативної державної політики у напрямі розбудови сільської місцевості до світових стандартів, а також реалізації державної підтримки та запровадження цільових, комплексних державних програм і стратегій, спрямованих на забезпечення розвитку територій сільської місцевості.

Без визначення стану розвитку сільських територій та вдосконалення науково-методичного інструментарію немождиво оцінити гостроту наявних соціально-економічних проблем сталого розвитку зазначених територій.

Здійснення такої оцінки уможливдюе процес виявлення зовнішніх та внутрішніх загроз соціально-економічного та екологічного характеру, сприяе розробці комплексу ефективних заходів щодо інституційного врегулювання, визначення ключових напрямів забезпечення розвитку сільських територій.

Висновки. Отже, основними методичними підходами до ефективного оцінювання розвитку сільських територій є підходи, що базуються на системності, функціональності та синергетичному ефекті.

Комплексна оцінка розвитку сільських територій адміністративних районів дасть змогу проаналізувати систему державного управління розвитком сільських територій; визначити систему цілей, головну мету і про- 
міжні результати; врахувати причинно-наслідкову залежність, виявити особливості управлінського впливу на функціонування та ефективність розвитку сільських територій.

Завдяки методологічним підходам до оцінки розвитку сільських територій можна виявити не лише проблеми сільського розвитку, а й причини їх виникнення та шляхи розв'язання завдань для досягнення стратегічної мети. Сучасні умови господарської діяльності потребують максимального удосконалення методів прогнозування та планування, які відповідатимуть викдикам часу і зможуть надати чітку картину стану досліджуваного процесу.

\section{СПИСОК ВИКОРИСТАНИХ ДЖЕРЕ}

1. Балабаєва 3. В., Овчаренко С. В., Росколотько І. А. та ін. Діагностика соціального розвитку регіону : наук. розробка - К. : НАДУ, 2010. -40 с.

2. Балдинюк В.М. Методичні підходи до оцінки комплексного розвитку сільських територій: електронний журнал.// Державне управління: удосконалення та розвиток. - 2011. - № 9. URL:

http://www.dy.nayka.com.ua/?op=1\&z=332 (дата звернення: 05.09.2019).

3. Барановський М.О. Наукові засади суспільно-географіного вивчення сільських депресивних територій України : монографія - Ніжин : ПП Аисенко М. М., 2009. - 396 c.

4. Бойко В.В., Пріоритети та інструменти розвитку сільських територій в системі забезпечення економічної безпеки України: монографія - Иьвів: Видавництво ННВК «АТБ», $2017-426$ с.

5. Валовий внутрішній продукт. Вікіпедія: вільна енциклопедія. URL: https:// uk.wikipedia.org/wiki/Валовий_внутрішній_продукт (дата звернення: 02.09.2019).

6. Губені Ю. Розвиток сільських територій: деякі аспекти европейської теорії і практики // Економіка України - 2007 - № 4 - С. 62-70.

7. Зінчук Т.О., Куцмус Н.М. Методологічні підходи до оцінки умов та результатів сільського розвитку// Вісник ЖНАЕУ. - 2010 - №1 - С. 3-11.

8. Індекс людського розвитку. Вікіпедія: вільна енц̧иклопедія. URL: https:// uk.wikipedia.org/wiki/\%D0\%86\%D0\%BD\%D0\%B4\%D0\%B5\%D0\%BA\%D1\%81_\% D0\%BB\%D1\%8E\%D0\%B4\%D1\%81\%D1\%8C\%D0\%BA\%D0\%BE\%D0\%B3\%D0\%BE_ \%D1\%80\%D0\%BE\%D0\%B7\%D0\%B2\%D0\%B8\%D1\%82\%D0\%BA\%D1\%83/ Індекс_ людського_розвитку (дата звернення: 02.09.2019).

9. Ключник А.В. Формування та розвиток економічного потенціалу сільських територій України: монографія. - Миколаїв: Дизайн та поліграфія, 2011. - 468 с.

10. Аісовий А.В. Сталий розвиток сільських територій: виникнення, сутність, принципи.// Економіка АПК. - 2007. - № 4. - С. 140-145.

11. Дісовий А.В. Державне регулювання розвитку сільських територій: теорія, методологія, практика: авторефер. дис. на здобуття наукового ступеня д.е.н.: 08.00.03 - Київ, 2009. - 27 с.

12. Миколайчук М.М. Методи та засоби діагностики економічного стану підприємств регіону. Вісник соціально-економічних досліджень: зб. наук. пр. - Одеса: ОДЕУ, 2003. - Вип.14 - С.218. - 222.

13. Миколайчук М.М. Діагностика соціально-економічного розвитку території як елемент механізму державного управління: авторефер. дис. на здобуття наукового ступеня канд. наук 3 держ. управдіння: 25.00.02 - Одеса, 2004. - 16 с. 
14. Павлов О.I. Сільські території України: історична трансформація парадигми управління: монографія - Одеса: Астропринт, 2006. - 360 с.

15. Регіони України. Економіко-статистичні порівняння (додаток до науково-практичного журналу “Регіональна економіка") - 2002. - № 1 - 75 с.

16. Севастянов И.И. Индикаторы социально-экономического развития регионов : методические подходы к разроботке // Регион : экономика и соціологія. 1996. № 1. - C. 44-58.

17. Тимошенко М.М. Методичні засади оцінки сталого розвитку сільських територій: алгоритм, структурна схема та інструментарій дослідження.// Економіка та управління національним господарством. - 2018. - №21. - С. 214-218.

18. Тлумачний словник термінів, пов'язаних із моніторингом та оцінкою ефективності: програма Європейського Союзу Тасіs / Проект СС «Підтримка у виконанні Угоди про партнерство та співробітництво (УПС)». - K., 2008. URL:http: www. esbs.kiev/ua (дата звернення: 02.09.2019).

19. Усюк Т.В., Фаріон Л.В. Методичні підходи до оцінки ефективності розвитку сільських територій за умов сталості // Економіка АПК. - 2018. - № 2.- С. 64-70.

20. Dirk B. Agriculture, Development, and Urban Bias / Bezemer Dirk, Derek Headey // World Development 36.8:1342-64.

21. Eisenhardt K. M. Building theories from case study research / K. M. Eisenhardt // The Academy of Management Review, 14 (4). Oct. P. 532-550.

\section{REFERENCES}

1. Balabaieva, Z. V., Ovcharenko, S. V., \& Roskolotko, I. L. ta in (2010). Diahnostyka sotsialnoho rozvytku rehionu [Diagnosis of social development of the region] (nauk. rozrobka). Kyiv: NADU [in Ukrainian].

2. Baldinyuk, V.M. (2011). Metodichni pidhodi do ocinki kompleksnogo rozvitku silskih teritorij [Methodical approaches to the assessment of integrated rural development]. Derzhavne upravlinnya: udoskonalennya ta rozvitok - Public administration: improvement and development, 9. Retrieved from http://www.dy.nayka.com.ua/?op=1\&z=332 [in Ukrainian].

3. Baranovskyi, M.O. (2009). Naukovi zasady suspilno-heohrafinoho vyvchennia silskykh depresyonykh terytorii Ukrainy [Scientific bases of socio-geographical study of rural depressed territories of Ukraine]. Nizhyn: PE Lysenko MM (electronic journal) [in Ukrainian].

4. Bojko, V.V. (2017). Prioriteti ta instrumenti rozvitku silskih teritorij v sistemi zabezpechennya ekonomichnoyi bezpeki Ukrayini [Priorities and instruments for rural development in Ukraine's economic security system]. Lviv: Publishing House of Scientific-Production Company «ATB» [in Ukrainian].

5. Valovij vnutrishnij product [Gross Domestic Product]. (n.d.). wikipedia.org. Retrieved from https://uk.wikipedia.org/wiki [in Ukrainian].

6. Hubeni, Yu. (2007). Rozvytok silskykh terytorii: deiaki aspekty yevropeiskoi teorii i praktyky [Rural development: some aspects of European theory and practice] Ekonomika Ukrainy, 4, 62-70 [in Ukrainian].

7. Zinchuk, T.O., \& Kutsmus, N.M. (2010). Metodolohichni pidkhody do otsinky umov ta rezultativ silskoho rozvytku [Methodological approaches to the assessment of minds and the result of social development]. Visnyk ZhNAEU, 1, 3-11 [in Ukrainian].

8. Indeks liudskoho rozvytku [Human Development Index]. wikipedia. org. Retrieved from https://uk.wikipedia.org/wiki/\%D0\%86\%D0\%BD\%D0\%B4\%D0\%B5\%D0\%BA\%D1\%81_\%D0\%BB\%D1\%8E\%D0\%B4\%D1\%81\%D1\%8 C\%D0\%BA\%D0\%BE\%D0\%B3\%D0\%BE_\%D1\%80\%D0\%BE\%D0\%B7\%D0\%B2\%D0\% B8\%D1\%82\%D0\%BA\%D1\%83 [in Ukrainian]. 
9. Kliuchnyk, A.V. (2011). Formuvannia ta rozvytok ekonomichnoho potentsialu silskykh terytorii Ukrainy [Formation and development of economic potential of rural territories of Ukraine]. Mykolayiv: Dyzayn ta polihrafiya [in Ukrainian].

10. Lisovyi, A.V. (2007). Stalyi rozvytok silskykh terytorii: vynyknennia, sutnist, pryntsypy [Sustainable development of rural territories: origin, nature, principles]. Ekonomika APK, 4, 140 - 145 [in Ukrainian].

11. Lisovyi, A.V. (2009) Derzhavne rehuliuvannia rozvytku silskykh terytorii: teoriia, metodolohiia, praktyka [State regulation of rural development: theory, methodology, practice]. Extended abstract of candidate's thesis. Kyiv [in Ukrainian].

12. Mykolaichuk, M.M. (2003). Metody ta zasoby diahnostyky ekonomichnoho stanu pidpryiemstv rehionu [Methods and means of diagnostics of economic status of enterprises of the region]. Visnyk sotsialno-ekonomichnykh doslidzhen, 14, 218 - 222 [in Ukrainian].

13. Mykolaichuk M.M. (2004). Diahnostyka sotsialno-ekonomichnoho rozvytku terytorii yak element mekhanizmu derzhavnoho upravlinnia [Diagnosis of socio-economic development of the territory as an element of the mechanism of public administration]. Extended abstract of candidate's thesis. Odesa [in Ukrainian].

14. Pavlov, O.I. (2006). Silski terytorii Ukrainy: istorychna transformatsiia paradyhmy upravlinnia [Rural territories of Ukraine: a historical transformation of the management paradigm]. Odesa: Astroprynt [in Ukrainian].

15. Rehiony Ukrainy. Ekonomiko-statystychni porivniannia [Regions of Ukraine. Economics and statistics (2002). Dodatok do naukovo-praktychnoho zhurnalu "Rehionalna ekonomika") - supplement to the scientific and practical journal "Regional Economics", 1, 75 [in Ukrainian].

16. Sevastianov, L.Y. (1996). Indekatory sotsyalno-ekonomycheskoho razvytyia rehyonov : metodycheskye podkhody $\mathrm{k}$ razrobotke [Indicators of socio-economic development of regions: methodological approaches to development]. Region: Economics and Sociology 1, 44-58 [in Russian].

17. Tymoshenko, M.M. (2018). Metodychni zasady otsinky staloho rozvytku silskykh terytorii: alhorytm, strukturna skhema ta instrumentarii doslidzhennia [Methodological bases for the assessment of sustainable development of rural areas: algorithm, block diagram and research tools]. Ekonomika ta upravlinnia natsionalnym hospodarstvom, 21, 214-218 [in Ukrainian].

18. Tlumachnyi slovnyk terminiv poviazanykh iz monitorynhom ta otsinkoiu efektyvnosti: prohrama Yevropeiskoho Soiuzu Tacis Proekt YeS «Pidtrymka u vykonanni Uhody pro partnerstvo ta spivrobitnytstvo [Interpretative glossary of terms related to monitoring and evaluation of performance: European Union Tacis Program / EU Project "Support to implementation of the Partnership and Cooperation Agreement]. Kyiv, 2008. Retrieved from http: www.esbs. kiev/ua [in Ukrainian].

19. Usiuk, T.V., \& Farion, L.V. (2018) Metodychni pidkhody do otsinky efektyvnosti rozvytku silskykh terytorii za umov stalosti [Methodical approaches to assessing the effectiveness of rural development under conditions of sustainability]. Ekonomika APK, 2, 64-70 [in Ukrainian].

20. Dirk, B. Agriculture, Development, and Urban Bias. World Development, 36.8:1342-64 [in English].

21. Eisenhardt, K. M. Building theories from case study research. The Academy of Management Review, 14 (4), 532-550 [in English]. 